\title{
Reassessment of the Systematic Position of Orthocomotis DoGNIN (Lepidoptera: Tortricidae) Based on Molecular Data with Description of New Species of Euliini
}

\author{
Józef RazOWSKI, Sebastian TARCZ, †Janusz WoJTUSIAK, and Volker PELZ
}

Accepted November 22, 2012

\begin{abstract}
Razowski J., TARCZ S., Wojtusiak J., Pelz V. 2013. Reassessment of the systematic position of Orthocomotis DoGNIN (Lepidoptera: Tortricidae) based on molecular data with description of new species of Euliini. Folia Biologica (Kraków) 61: 125-134.

The application of molecular analyses for resolving taxonomic problems in the family Torticidae (Lepidoptera) is still uncommon. The majority of papers concern the assessment of population variability of economically important species; reports on the systematic positions of Neotropical Tortricidae taxa are rare. The Neotropical genus Orthocomotis was classified initially as a member of the tribe Euliini. Then, based on genital morphology, it was moved to the tribe Polyorthini. A comparison of homologous $606 \mathrm{bp}$ fragments of the COI mitochondrial gene revealed that Orthocomotis should be transfered back into the tribe Euliini. Based on an analysis of phylogenetic relationships the studied genera of Euliini form a monophyletic cluster, clearly separated from tribe Polyorthini in which they were temporarily included. Moreover, in the current paper we describe two new species of the tribe Euliini: Galomecalpa lesta RAZOWSKI \& PELZ, sp. n., Gauruncus ischyros RAzOWSKI \& PELZ, sp. n.
\end{abstract}

Key words: Tortricidae, Orthocomotis, molecular phylogeny, mitochondrial COI.

JózefRAZOWSKI, Department of Invertebrate Zoology, Institute of Systematics and Evolution of Animals, Polish Academy of Sciences, 31-016 Kraków, Stawkowska 17, Poland. E-mail:razowski@isez.pan.krakow.pl

Sebastian TARCZ, Department of Experimental Zoology, Institute of Systematics and Evolution of Animals, Polish Academy of Sciences, 31-016 Kraków, Stawkowska 17, Poland.

E-mail:tarcz@isez.pan.krakow.pl

† Janusz WOJTUSIAK, Zoological Museum, Jagiellonian University, Ingardena 6, 30-060

Kraków, Poland.

Volker PELZ, Bonnenweg 3, D-503809 Ruppichteroth, Germany.

The Tortricidae, a family of Lepidoptera with global occurrence, consists of about 10000 described species (BROWN 2005) of which a large number do not have clearly defined taxonomic positions. A taxonomic system based on morphological characters of members of this family has been improved for more than 150 years, but, as in most other insect groups, is far from definite. Comparative analysis of genome fragments provides an opportunity for taxonomic progress and determination of the relationships among various taxa.

Information on the applications of molecular markers in Torticidae for the identification of the systematic position of particular taxa is rather sparse. Most evaluate the population structure of economically important species, for example Tortrix viridana (SCHROEDER \& DEGEN 2008), Tortricidae from South Africa (TIMM et al. 2010) or the Choristoneura fumiferana (LUMLEY \& SPER-
LING 2011) species complex. The earliest analyses were based on allozyme comparisons, for example the degree of genetic differentiation of the larch budmoth Zeiraphera diniana was studied using 24 allozyme loci (EMELIANOV et al. 1995). Subsequently, methods based on PCR began to play a more significant role. Introgression between two closely related species of the genus Choristoneura was confirmed by RAPD markers (DEVERNO et al. 1998). Another approach, AFLP markers, was successfully applied for reconstruction of the phylogenetic position of Cydia pomonella (THALER et al. 2008).

Sequencing homologous DNA fragments provides an opportunity for the parallel analysis of a larger number of features than in the methods mentioned above. However studies of intra-specific relationships among Torticidae taxa are mostly based on comparisons of mitochondrial genome 
fragments, especially the cytochrome oxidase gene $(C O I)$. For example, the phylogenetic relationships of Argyrotaenia franciscana were determined by analysis of a mitochondrial DNA fragment containing the genes $\mathrm{COI}$ and $\mathrm{COII}$ (2300 bp) (LANDRY et al. 1999). A similar analysis using the $C O I$ segment was carried out by comparing sequences obtained from closely related species of the genus Archips (KRUSE \& SPERLING, 2002). A 940 bp COI fragment was applied to discriminate between two forms of Adoxophyes orana feeding on different food plants in the Adoxophyes species complex (LEE et al. 2005).

A combination of morphological and molecular data was useful for verification of the systematic position of the European Tortricini (RAZOWSKI et al. 2010) and for resolving uncertain relationships between tribes Bactrini and Endotheniini (RAZOWSKI $\&$ TARCZ 2012). However, such analyses have not been applied to Neotropical Torticidae genera.

For the first time genus Orthocomotis was described for one Neotropical species. Orthocomotis didn't have a tribal placement and was treated as a member of Tortricinae. CLARKE (1955) was the first to revise the genus and included in it 29 species (12 previously known and 17 newly described species). His supposition that Orthocomotis is a genus was confirmed by further studies (RAZOWSKI et al. 2007).

Then RAZOWSKI (1982) transferred Orthocomotis to Polyorthini, a tribe of the subfamily Chlidanotinae based on the following synapomorphy: a minutely bristled dorsal portion of the anellus situated immediately above the aedeagus, connected with the aedeagus and transtilla.

According to POWELL (1986) this genus belongs in Euliini. However, POWELL (1986) based his analysis only on some synplesiomorphies of the genitalia.

Finally BROWN (1989) transferred Orthocomotis and its closely related genus Paracomotis RAZOWSKI, 1982 to Schoenotenini based on the chaetosema situated on the vertex of the head. He also confirmed a previous hypothesis (DIAKONOFF 1974) that the most important character of Polyorthini is the presence of the outer slit of the valva and its associated corema (a scalepencil from the terminal part of the abdomen concealed in a slit). However, there are many closely related species of Chlidanotinae with a secondarily reduced abdominal scent organ.

Recently, there was a consensus that the discussed genus belongs to Euliini (HORAK 1999; HORAK \& BROWN 1991; RAZOWSKI 2008) although RAZOWSKI and BECKER (1999) suggested that the true phylogenetic placement of Orthoco- motis requires further study. The purpose of the present study is to elucidate this issue.

In the present paper we compared several species of Orthocomotis forming a compact grouping and used four representative species. We compared Orthocomotis with six species of Polyorthini and Palaearctic Eulia ministrana, the type-species of the genus Eulia, and five representatives of the Neotropical Euliini. In the Palaearctic there is another species (Pseudargyrotoza conwagana FABRICIUS, 1775) but there are some objections if it belongs to Euliini (HORAK 1999). In the Neotropics there are numerous species of Euliini which are included in the tribe on the basis of presence of the pedal scent organ.

Because of the uncertain position of Orthocomo$t i s$, we proposed a preliminary molecular approach as a tool for resolving this taxonomic problem. The present paper is the first comparative molecular study of representatives of the studied species.

\section{Material and Methods}

\section{Material}

The examined specimens were collected by Janusz WOJTUSIAK and Volker PELZ in Ecuador and are preserved in the collection of the Zoological Museum of the Jagiellonian University, Kraków (MZUJ) and the Volker PELZ collection. Due to problems associated with obtaining good quality DNA suitable for molecular analysis, $C O I$ sequences of Eulia ministrana were taken from GenBank. Representatives of the tribe Olethreutini i.e. Apotomis inudana, Apotomis sauciana, Olethreutes arcuellus were used as outgroups. A list of examined taxa arranged alphabetically is presented in Table 1.

\section{Molecular methods}

DNA was extracted only from two hind legs of dry specimens because some of them were museum material (it was impossible to use other parts of the bodies - e.g. the entire tagmata) and preserved in $70 \%$ alcohol. The examined specimens were not older than 10 years and were first identified by comparison of the genitalia. Specimens over ten years of age usually gave insufficient results. The best results were obtained from 1-3 year old individuals preserved in $70 \%$ alcohol.

Genomic DNA was isolated without protocol modification using the NucleoSpin Tissue Kit (Macherey-Nagel, Germany). To elute purified DNA we applied $100 \mu \mathrm{l}$ of Elution Buffer (EB) onto the silica membrane. To amplify a fragment of the 


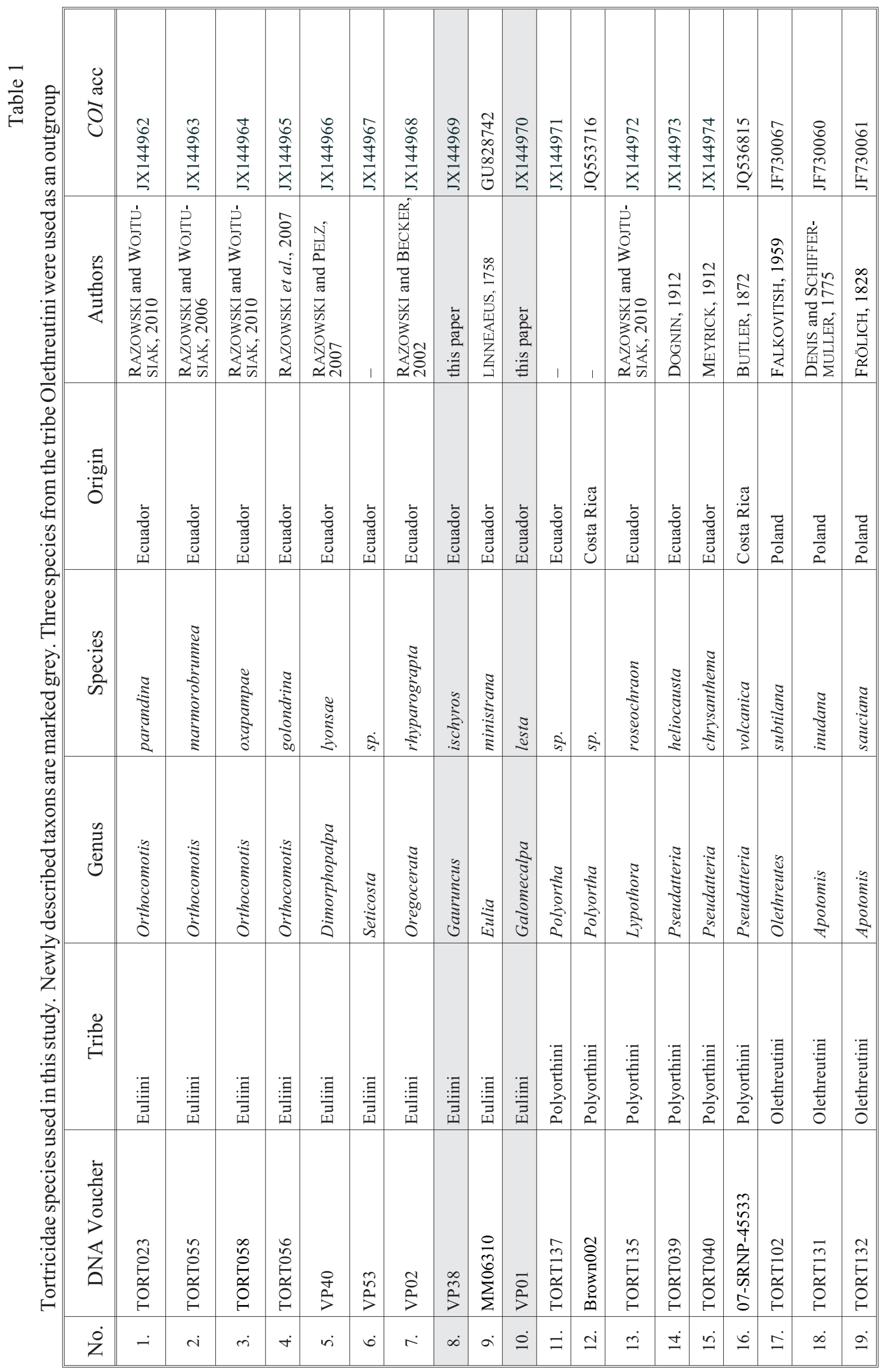


mitochondrial COI gene (650bp) the following primer pair designed for Lepidoptera was used: LEP-F1, 5'-ATTCAACCAATCATAAAGATAT-3'; and LEP-R1, 5'-TAAACTTCTGGATGTCCAAAAA-3'. These are universal primers used for species identification in DNA barcoding (HEBERT et al. 2004). PCR amplification of both markers was carried out in a final volume of $40 \mu \mathrm{l}$ containing: $4 \mu \mathrm{l}$ of template, 1.5 U Taq-Polymerase (EURx, Poland), $0.8 \mu \mathrm{l}$ of each $20 \mu \mathrm{M}$ primer, 10x PCR buffer, $0.8 \mu \mathrm{l}$ of $10 \mathrm{mM}$ dNTPs in a Mastercycler ep (Eppendorf, Germany). The amplification protocol was the same as in (HEBERT et al. 2004). To check amplification, $10 \mu$ of each PCR product was electrophoresed in $1 \%$ agarose gel for $45 \mathrm{~min}$ at $85 \mathrm{~V}$ with a DNA molecular weight marker (Mass Ruler Low Range DNA Ladder, Fermentas, Lithuania). For purification of PCR reactions we used NucleoSpin Extract II (Macherey-Nagel, Germany). In some of the PCR reactions apart from main band additional sub-bands were obtained. In these cases $30 \mu$ of each PCR product was separated on a $1.8 \%$ agarose gel $(100 \mathrm{~V} / 60 \mathrm{~min})$. Then, the band representing the examined fragment was cut out and purified.

Cycle sequencing was done in both directions with the application of BigDye Terminator v3.1 chemistry (Applied Biosystems, USA). Primers LEP-F1 and LEP-R1 were used for sequencing. Each sequencing reaction was carried out in a final volume of $10 \mu \mathrm{l}$ containing: $3 \mu \mathrm{l}$ of template, $1 \mu \mathrm{l}$ of BigDye Master Mix (1/4 of standard reaction), $1 \mu$ l of sequencing buffer, $1 \mu \mathrm{l}$ of $5 \mu \mathrm{M}$ primer. Sequencing products were precipitated using Ex Terminator (A\&A Biotechnology, Poland) and separated on an ABI PRISM 377 DNA Sequencer (Applied Biosystems, USA). Sequences are available in the GenBank database (for accession numbers see Table 1).

\section{Data analysis}

Sequences were examined using Chromas Lite (Technelysium, Australia) to evaluate and correct chromatograms. The alignment of the studied sequences was performed using ClustalW (THOMPSON et al. 1994) within the BioEdit software (HALL 1999). Phylograms were constructed for the studied fragments with Mega v5.0 (TAMURA et al. 2011) using neighbor-joining [NJ, (SAITOU \& NEI 1987)], maximum parsimony [MP, (NEI \& KUMAR 2000)], and maximum likelihood [ML, (FELSENSTEIN 1981)]. NJ analysis was performed using the Kimura 2-parameter correction model (KIMURA 1980) by bootstrapping with 1000 replicates (FELSENSTEIN 1985). MP analysis was evaluated with the min-min heuristic parameter (at level 2) and bootstrapping with 1000 replicates. Bayesian in- ference (BI) was performed with MrBayes 3.1.2 (RONQUIST \& HUELSENBECK 2003); the analysis was run for 5,000,000 generations and trees were sampled every 100 generations. All trees were examined with TreeView 1.6.6 (PAGE 1996). Analysis of haplotype diversity, nucleotide diversity and variable nucleotide positions was done with DnaSP v5.10.01 (LIBRADO \& ROZAS 2009). Analysis of nucleotide frequencies, p-distance estimation and identification of substitution model $(\mathrm{GTR}+\mathrm{G}+\mathrm{I}$ for $\mathrm{COI} \mathrm{mtDNA}$ fragments) for $\mathrm{ML}$ analysis were done with Mega v5.0 (TAMURA et al. 2004, 2011).

\section{Results and Discussion}

A total of 19 sequences of the gene encoding cytochrome oxidase subunit I (606 bp) from species of Euliini, Polyorthini and Olethreutini were used in this study. Of these, 13 were newly obtained while the remaining sequences were taken from GenBank.

The interspecific haplotype diversity value was $\mathrm{Hd}=1$, indicating substantial variability of the studied DNA fragment. Nucleotide diversity amounted to $\pi=0.1114$. The nucleotide frequencies were $\mathrm{A}=0.3119, \mathrm{~T}=0.3716, \mathrm{C}=0.1554 \mathrm{G}=0.1611$ and revealed a high proportion of A-T pairs which corresponds with typical characteristics of insect mitochondrial DNA. Mean divergence over all studied Tortricidae $(\mathrm{N}=19)$ sequence pairs was $\mathrm{p}=0.111 / \mathrm{SE}=0.007 \quad$ ( $\mathrm{p}$-distance/standard error). Mean divergence over all studied Euliini $(\mathrm{N}=10)$ sequence pairs was $\mathrm{p}=0.113 / \mathrm{SE}=0.008$ and Polyorthini $(\mathrm{N}=6)(\mathrm{p}=0.076 / \mathrm{SE}=0.007)$. More detailed information on divergences between particular species is presented in Table 2.

We found 198 variable positions across all studied species in the COI fragment, 156 of which were parsimony informative ( 90 with two variants, 51 three variants, 15 - four variants). A total of 19 haplotypes were found among the studied species.

All constructed trees (Figs 1-3) showed the existence of three well separated clusters representing the particular tribes (Euliini, Polyorthini and Olethreutini used as an outgroup). Orthocomotis always appears in the Euliini cluster. In the case of $\mathrm{NJ}$ and MP, it forms a monophyletic cluster with closely related $O$. parandina and $O$. marmorobrunea, then $O$. oxapampae and most distant $O$. golondrina. The latter species in ML and BI trees appears together with Dimorphopalpa lyonsae. This could be connected with the applied COI gene which is a fast evolving genome fragment. This could be seen on the constructed trees: the terminal branches are very long with high boot- 


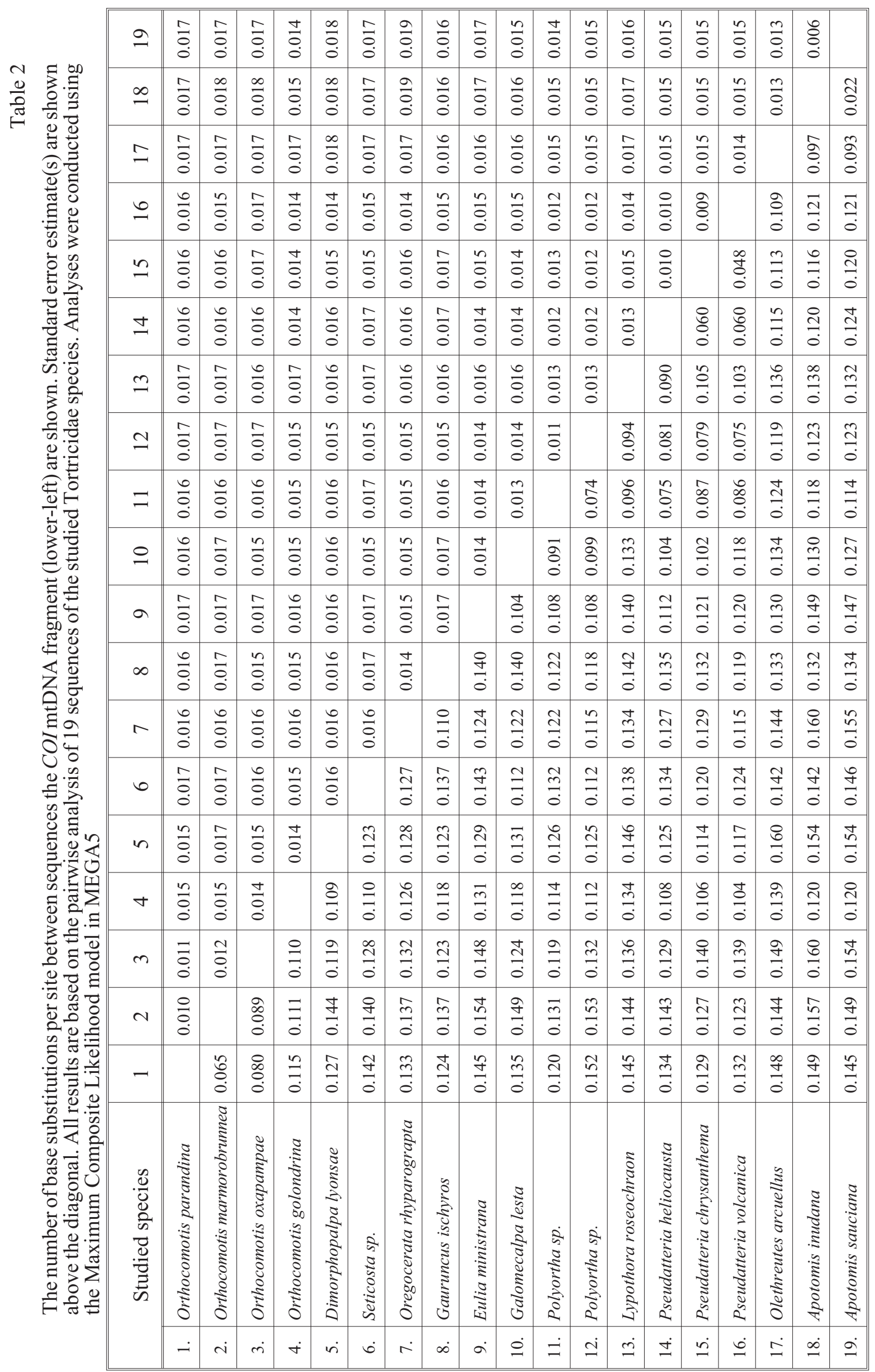




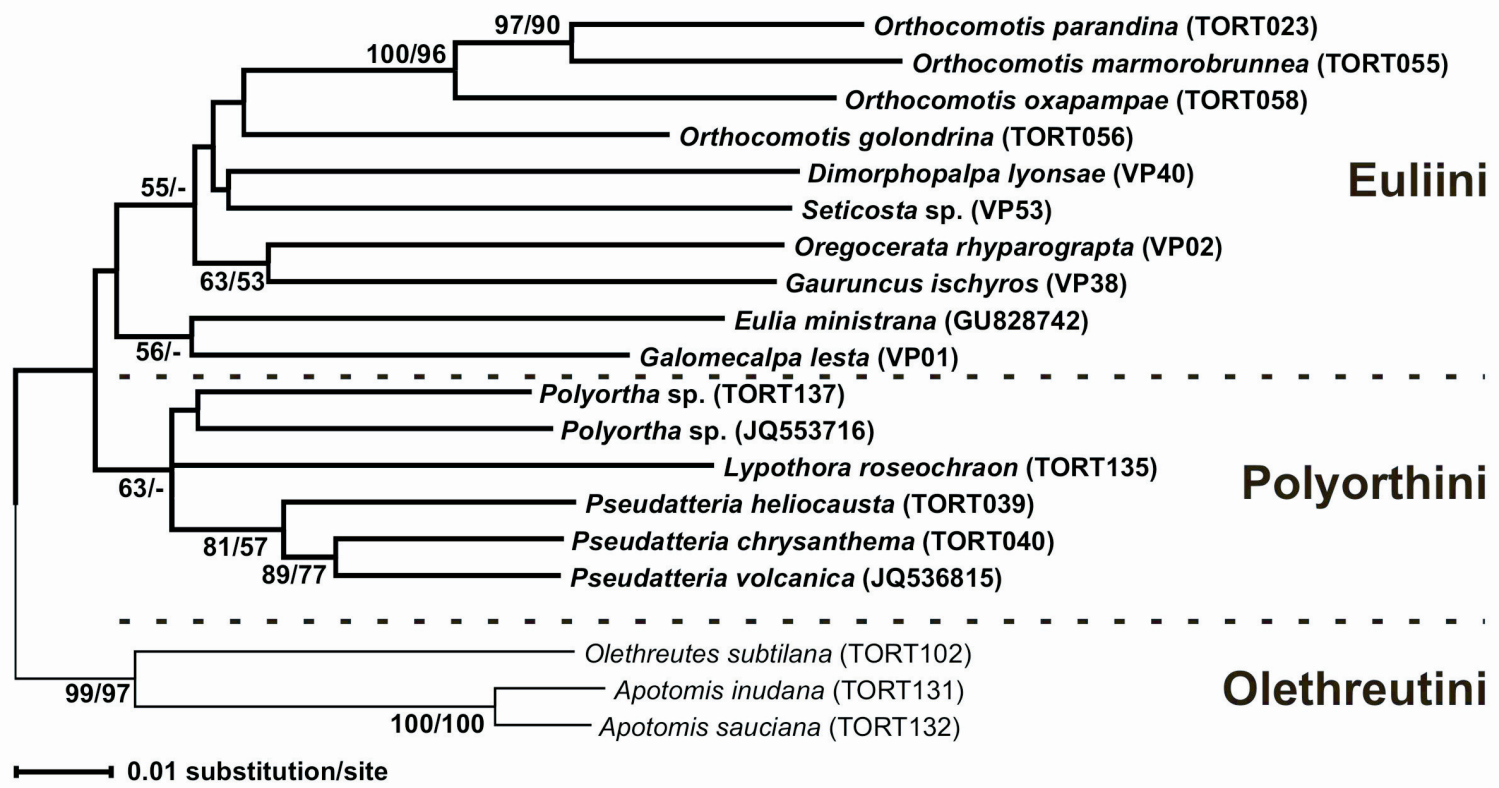

Fig. 1. Phylogenetic tree constructed for 16 species of Euliini and Polyorthini (three species of Olethreutini were used as an outgroup). The evolutionary history was inferred using the Neighbor-Joining and Maximum Parsimony methods. The bootstrap consensus tree inferred from 1000 replicates is taken to represent the evolutionary history of the taxa analyzed. The percentage of replicate trees in which the associated taxa clustered together in the bootstrap test (1000 replicates) are shown next to the branches. The evolutionary distances were computed using the p-distance method and are in the units of the number of base differences per site. The analysis involved 19 nucleotide sequences. There were a total of 606 positions in the final dataset.

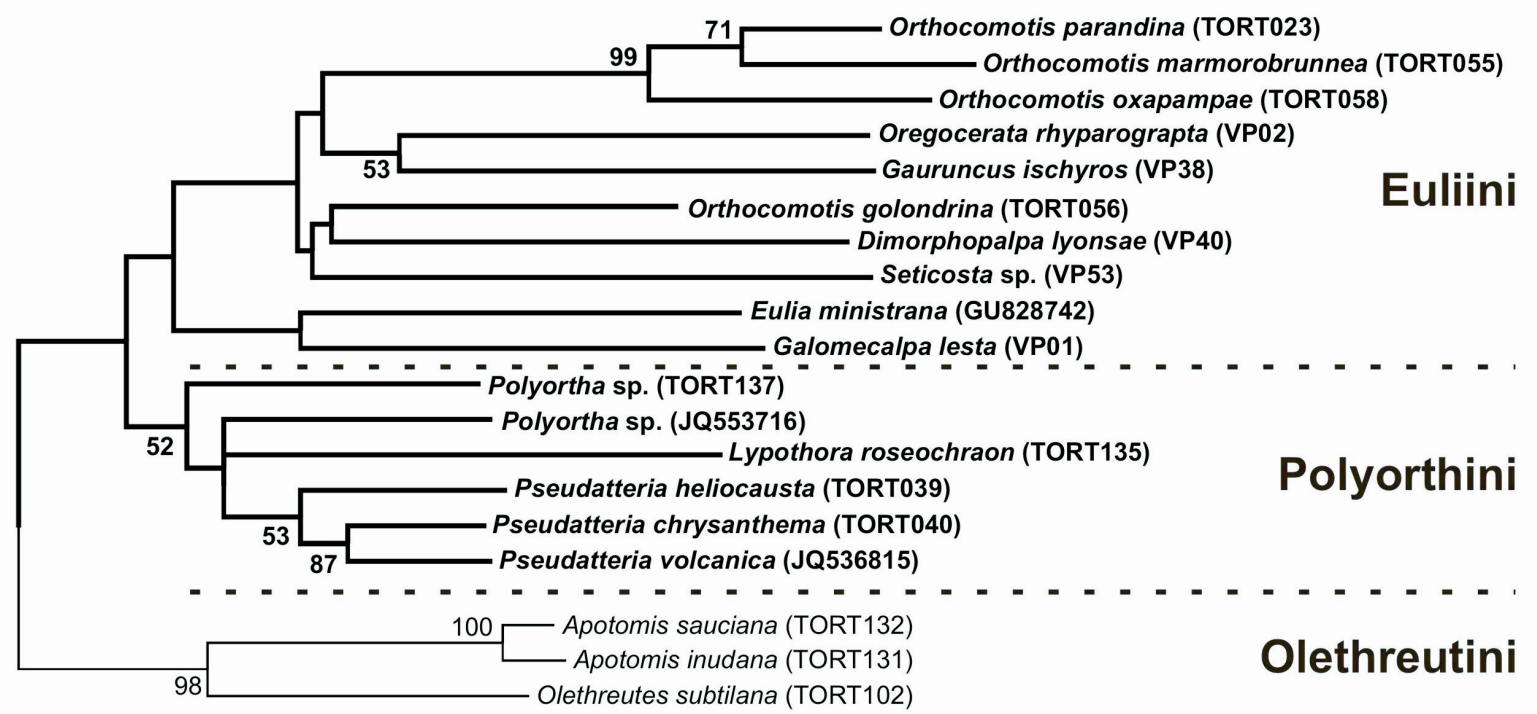

0.02 substitution/site

Fig. 2. Phylogenetic tree constructed for 16 species of Euliini and Polyorthini (three species of Olethreutini were used as an outgroup). The evolutionary history was inferred using the Maximum Likelihood method. The bootstrap consensus tree inferred from 1000 replicates is taken to represent the evolutionary history of the taxa analyzed. The percentage of replicate trees in which the associated taxa clustered together in the bootstrap test (1000 replicates) are shown next to the branches. The evolutionary distances were computed using the $\mathrm{p}$-distance method and are in the units of the number of base differences per site. The analysis involved 19 nucleotide sequences. There were a total of 606 positions in the final dataset. 


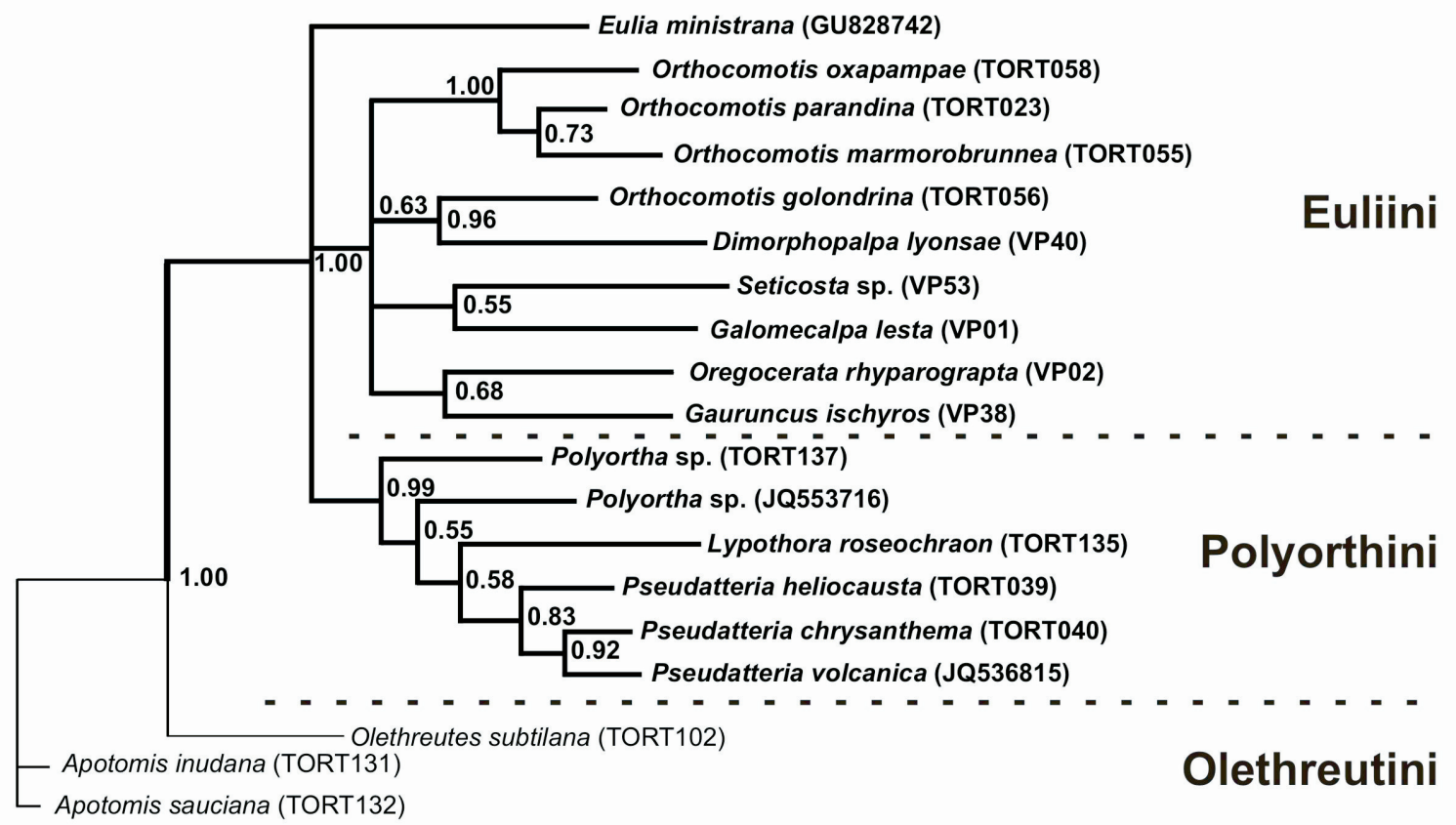

0.1 substitution/site

Fig. 3. Phylogenetic tree constructed for 16 species of Euliini and Polyorthini (three species of Olethreutini were used as an outgroup). The evolutionary history was inferred using the Bayesian Inference method. The posterior probabilities are shown next to the branches. The analysis involved 19 nucleotide sequences. There were a total of 606 positions in the final dataset.

strap/posterior support for external nodes. However, in the present analysis we were not able to obtain DNA sequences for other, more slowly evolving molecular markers. Nonetheless, all studied species of Polyorthini are well separated from each other and support the DNA barcoding hypothesis (HEBERT et al. 2003) that the COI fragment can be used as a universal molecular marker for species differentiation. As mentioned above, we obtained similar trees using ML and BI methods (Figs 2, 3) with one exception. Orhocomotis golondrina appeared as closely related to Dimorphopalpa lyonsae. The morphological approach contradicts this discrepancy but we cannot exclude that the two genera are related. This result may be thus regarded as preliminary and a further analysis with additional species of Dimorphopalpa and specimens of $O$. golondrina is required. This issue does not contradict the purpose of this paper, the inclusion of Orthocomotis in the Euliini.

The two new species of Euliini: Galomecalpa lesta RAZOWSKI \& PELZ, sp. n., Gauruncus ischyros RAZOWSKI \& PELZ, sp. n., do not seem to be closely related (Figs 1-3). Galomecalpa lesta appears together with Eulia ministrana, the type species of Euliini, on NJ, MP or ML trees but on BI tree is in one cluster with Seticosta sp. On the other hand, in all analyzed trees Gauruncus ischyros
(Figs 1-3) is closely related to Oregocerata rhyparograpta.

Our molecular study confirms the supposition by BROWN (1989) that Orthocomotis seems to be a genetically differentiated genus belonging to Euliini and is not directly related to Polyorthini. This large genus, certainly with unexamined Paracomotis RAZOWSKI, 1982 constitutes, however, a distinct clade and probably the sister group to other Euliini.

There are some morphological characters that differentiate between Euliini and Polyorthini. The valvan slit correlated with the corema is always absent in the discussed genus but a lack of the slit is also noted in several Polyorthini and the two remaining tribes of Polyorthinae. Instead, males of Orthocomotis have a developed anterior abdominal scent organ not found in Polyorthini but occurring in several genera of the Tortricidae, e.g. in Pandemis HÜBNER, Tortricinae and Lobesia GUENÉE, Olethreutinae. However, the pedal scent organ characteristic of Eulia HÜBNER is found in Atteriini. Apparently, the distribution of scent organs within the family is of convergent importance (legs, basal and terminal parts of abdomen are convenient places for scent gland distribution). The microspined dorsal part of the anellus developed in Orthocomotis is widely distributed within Poly- 
orthini and the remaining tribes of Chlidanotinae. However, Orthocomotis lacks a distinctly sclerotized link between the juxta and disc of valva which are present in Polyorthini.

A comparison of the system based on morphology of Tortricidae with molecular analysis of selected DNA fragments should facilitate the resolution of problematic relationships between species, genera and tribes. Furthermore, it will improve and complete the current system of Tortricidae classification, and should help in assessment of the frequency of cryptic species occurrence or sex identification in case of dimorphic species.

\section{Systematic Appendix}

The descriptions of two previously unknown species are below. Their holotypes are preserved in the Volker PELZ Collection, Ruppichteroth, Germany and eventually will be deposited in the Senckenberg Museum, Frankfurt/Main.

\section{Galomecalpa lesta RAZOWSKI \& PELZ, sp. n.}

(Fig. 4 A, B, C)

Des cription. Wingspan $14 \mathrm{~mm}$. Head and thorax brownish cream. Forewing hardly expanding terminally; apex rounded; temen slightly oblique and convex. Ground colour brownish cream; strigulation brownish. Markings brown: basal blotch preserved in form of a costal suffusion; postbasal fascia distinct; subtriangular costal blotch with darker marks and whitish spot at end of median cell; fascia from tornus convex; three spots subapically. Cilia (rubbed) concolorous with ground colour. Hindwing cream tinged brownish, strigulated brownish grey; cilia cream.

Male genitalia (Fig. 4 A, B). Uncus simple, slender; socius large; arm of gnathos with median prominence; valva broad at base; sacculus angulate postbasally, with small terminal prominence; median part of transtilla convex; aedeagus broad beyond zone, then slender, bent.

Female unknown.

Holotype male: "Ecuador, Pastaza - Prov., Puyo, $2 \mathrm{~km}$ NW Shell, Los Copales, $1075 \mathrm{~m}$ a.s.l., $1^{\circ} 29^{\prime} 25^{\prime \prime} \mathrm{S}$ 7804'17" W, 27-29.I.2009, leg. Volker PELZ", GU-4408-V.P. (Fig. 4 C).

$\mathrm{D}$ i a $\mathrm{g} \mathrm{n}$ o s i s. Galomecalpa lesta is closely related to G. meridiana RAZOWSKI \& BROWN, 2004 from Venezuela which was incorrectly recorded from Ecuador by RAZOWSKI \& PELZ (2006) from the Napo Province but the latter with long, slender aedeagus similar to $G$. parsonsi RAZOWSKI \&
PELZ, 2006. The two Ecuadoran species are illustrated by RAZOWSKI \& PELZ 2006.

Etymology. The specific name refers to a forgotten species; Greek: lestis - oblivion.

Gauruncus ischyros RAZOWSKI \& PELZ, sp. n.

(Fig. 4 D, E, F)

D e s c r i p ti on. Wingspan: Holotype male $16 \mathrm{~mm}$, Paratypes males $16-17 \mathrm{~mm}$. Head and thorax brown tinged ferruginous. Forewing rather not expanding terminally; costa convex at base; termen slightly concave beneath apex. Ground colour creamish tinged brown-grey, with ferruginous suffusions and brown spots, pale terminally. Markings brown with rust and brown shades, in the form of indistinct basal blotch and costal blotch with white median spot at costa followed by three weak whitish spots. Cilia brownish olive. Hindwing brownish cream; cilia similar.

Male genitalia (Fig. 4 D, E). Tegumen rather short; uncus two strongly sclerotized tapering apically processes and small median prominence; socius broad; gnathos arms slender, terminal plate oval; sacculus with elongate ventrobasal part and strong termination; transtilla a simple band with well sclerotized dorsum; aedeagus broad, bilobed; vesica with long sclerite consisting of five fused scales.

Female unknown.

Holotype, male: "Ecuador, Pichincha - Prov., 7 km SW Tandayapa, Bellavista Research Station, $2300 \mathrm{~m}$ a.s.1., $0^{\circ} 0{ }^{\prime} 41^{\prime \prime} \mathrm{S} 78^{\circ} 41^{\prime} 17^{\prime \prime} \mathrm{W}$ 25-27.II.2009, leg. Volker PELZ", GU-4764-V.P. (Fig. 4 F).

Paratypes (3): 1 male (GU-3845-V.P.): Ecuador, Pichincha-Prov., $2.5 \mathrm{~km}$ SE Santa Rosa, Reserva Las Gralarias, $2068 \mathrm{~m}$ a.s.1., $0^{\circ} 0{ }^{\prime} 37^{\prime \prime} \mathrm{S} 78^{\circ} 43^{\prime} 50^{\prime \prime} \mathrm{W}$, 5-7.XI.2007, leg. Volker Pelz, 2 males (GU-3796-V.P., GU-3796-V.P.): Ecuador, Pichincha-Prov., $6 \mathrm{~km}$ S Santa Rosa, Las Gralarias, Damuth Choco Research Station, $2270 \mathrm{~m}$ a.s.1., $0^{\circ} 1^{\prime} 59^{\prime \prime} \mathrm{S} 78^{\circ} 42^{\prime} 33^{\prime \prime} \mathrm{W}$, 8-9.XI.2007, leg. Volker PELZ.

$\mathrm{D}$ i a $\mathrm{g}$ n o s i s. In facies, G. ischyros is similar to G. rossi RAZOWSKI \& PELZ, 2006 from Pichincha, Ecuador but does not have the ferruginous shading of the forewing ground colour; in genitalia ischyros resembles G. armatus RAZOWSKI, \& PELZ, 2006 but ischyros has short terminal process of the sacculus and slenderer arms of the uncus.

Etymology. The specific epithet refers to heavily sclerotized, large parts of genitalia; Greek: ischyros - strong. 

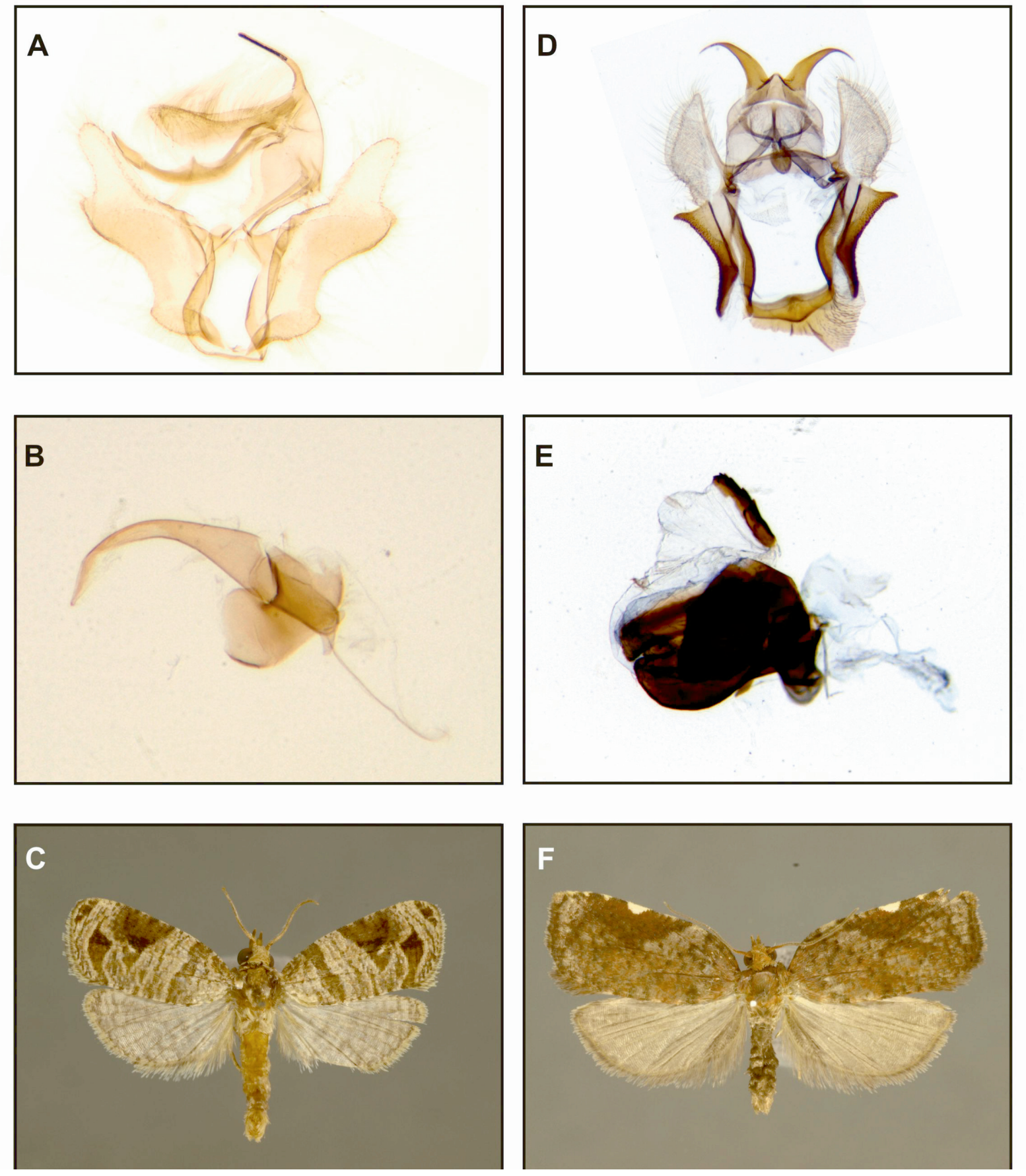

Fig. 4. A, B - male genitalia of Galomecalpa lesta sp. n., holotype, C - adult, same specimen; D, E - male genitalia of Gauruncus ischyros sp. n. holotype, $\mathrm{F}$ - adult, same specimen.

\section{References}

BRown J. W. 1989. New tribal Assignment for Orthocomotis Dognin and Paracomotis Razowski based on an unusual modification of the chaetosema (Lepidoptera: Tortricidae). Pan-Pacif. Ent. 65: 454-457.

BROWN J. W. 2005. Tortricidae (Lepidoptera). (In: World Catalogue of Insects. Apollo Books, Stenstrup, Denmark) 5 : 1-741.

CLARKE J. F. G. 1955. Neotropical moths of the genus Orthocomotis Dognin (Lepidoptera: Tortricidae). Trans. R. Entomol. Soc. London 107: 139-168.
Deverno L. L., SMith G. A., HARrison K. J. 1998. Randomly Amplified Polymorphic DNA evidence of introgression in two closely related sympatric species of coniferophagous Choristoneura (Lepidoptera: Tortricidae) in atlantic Canada Ann. Entomol. Soc. Am. 91: 248-259.

DiAKONOFF A. 1974. The South Asian Polyorthini with notes on species of Polyortha Dognin (Lepidoptera, Tortricidae). Zool. Verh. Leiden 131: 3-86.

EMELIANOV I., MALLET J., BALTENSWEILER W. 1995. Genetic differentiation in Zeiraphera Indiana (Lepidoptera: Tortricidae, the larch budmoth): polymorphism, host races or sibling species? Heredity 75: 416-424. 
FELSENSTEIN J. 1981. Evolutionary trees from DNA sequences: a maximum likelihood approach. J. Mol. Evol. 17: 368-376.

FELSENSTEIN J. 1985. Confidence limits on phylogenies: an approach using the bootstrap. Evolution 39: 783-791.

HALL T. A. 1999. BioEdit: a user-friendly biological sequence alignment editor and analysis program for Windows 95/98/NT. Nucl. Acids S. 41: 95-98.

HeBert P. D., CYWinska A., BAll S. L., DEWAard J. R. 2003. Biological identifications through DNA barcodes. Proc. R. Soc. Lond. B. 270: 313-321.

Hebert P. D., Penton E. H., Burns J. M., Janzen D. H., HALLWACHS W. 2004. Ten species in one: DNA barcoding reveals cryptic species in the neotropical skipper butterfly Astraptes fulgerator. Proc. Natl. Acad. Sci. U.S.A. 101 14812-14817.

HORAK M. 1999. Tortricoidea (In: Lepidoptera, moths and butterflies. Volume 1: Evolution, systematics, and biogeography. Handbook of Zoology 4. N. P. Kristensen ed. M. Fischer, Walter de Gruyter, Berlin - New York): 200-251.

HORAK M., BROWN R. L. 1991. Taxonomy and phylogeny (In: Tortricid pests their biology, natural enemies and control. E. S. Nielsen, E. D. Edwards, H. H. Evenhuis eds. Elsevier, Amsterdam - Oxford-New York-Tokyo): 23-48.

KIMURA M. 1980. A simple method for estimating evolutionary rates of base substitutions through comparative studies of nucleotide sequences. J. Mol. Evol. 16: 111-120.

KRUSE J. J., SPERLing F. A. H. 2002. Phylogeny of Nearctic species of the Xylosteana group of Archips Hübner (Lepidoptera: Tortricidae) based on combined analysis of the morphological and mitochondrial DNA datasets. Ann. Entomol. Soc. Am. 95: 288-301.

LANDRy B., Powell J. A, Sperling F. A. H. 1999. Systematics of the Argyrotaenia franciscana (Lepidoptera: Tortricidae) Species Group: Evidence from Mitochondrial DNA Ann. Entomol. Soc. Am. 92: 40-46.

LeE S. Y., PARK H., Boo K. S., PARK K. T., Cho S. 2005. Molecular identification of Adoxophyes honmai (Yasuda) (Lepidoptera: Tortricidae) based on mitochondrial COI gene sequences. Mol, Cells. 19: 391-397.

LibRADO P., ROZAS J. 2009. DnaSP v5: A software for comprehensive analysis of DNA polymorphism data. Bioinformatics 25: 1451-1452.

LUMLEY L. M., SPERLING F. A. 2011. Utility of microsatellites and mitochondrial DNA for species delimitation in the spruce budworm Choristoneura fumiferana species complex (Lepidoptera: Tortricidae). Mol. Phylogenet. Evol. 58: 232-243.

NeI M., Kumar S. 2000. Molecular Evolution and Phylogenetics. Oxford University Press, New York.

PAGE R. D. M. 1996. TreeView: An application to display phylogenetic tress on personal computers. Bioinformatics 12: $357-358$.

POWELL A. J. 1986. Synopsis of the classification of Neotropical Tortricinae, with description of new genera and species (Lepidoptera: Tortricidae). Pan-Pacif. Ent. 62: 372-398.
RAZOWSKI J. 1982. Notes on Orthocomotis Dognin (Lepidoptera: Tortricidae) with descriptions of new taxa. Bull. Acad. Polon. Sci. (Nat. Sci.) 30: 29-36.

RAZOWSKI J. 2008. Tortricidae of the Palaearctic Region, Volume 1 Tortricini and General Part. Frantisek Slamka. Bratislava, Kraków.

RAZOWSKI J., BECKER V. O. 1999. Descriptions and notes on Orthocomotis Dogning (Lepidoptera: Tortricidae). Acta zool. cracov. 33: 345-365.

RAZOWSKI J., PELZ V. 2006. Gauruncus Razowski, 1988 and Galomecalpa Razowski, 1990 from Ecuador (Lepidoptera: Tortricidae: Euliini). SHILAP Revista Lepid. 34: 289-303.

RaZOWski J., Pelz V., WoJTusiaK J. 2007. Orthocomotis Dognin, 1905 (Lepidoptera: Tortricidae) from Ecuador. Acta zool. cracov. 50B: 1-25.

RAZOWSKI J., TARCZ S. 2012. Molecular data on the systematic position of Bactrini (Lepidoptera: Tortricidae). Genus 23: $153-162$.

RAZOWSKi J., TARCZ S., GRECZEK-STACHURA M. 2010. Molecular approach to the systematics of European Tortricini (Lepidoptera: Tortricidae). Folia Biol. (Kraków) 59: 189-194.

RONQUIST F., HUELSENBECK J. P. 2003. MrBayes 3: Bayesian phylogenetic inference under mixed models. Bioinformatics 19: 1572-1574.

SAITOU N., NEI M. 1987. The neighbor-joining method: a new method for reconstructing phylogenetic trees. Mol. Biol. Evol. 4: 406-425.

Schroeder H., Degen B. 2008. Genetic structure of the green oak leaf roller (Tortrix viridana L.) and one of its hosts, Quercus robur L. For. Ecol. Manage. 256: 1270-1279.

TAMURA K., NeI M., KuMAR S. 2004. Prospects for inferring very large phylogenies by using the neighbor-joining method. Proceedings of the Nat. Acad. Sci. U.S.A 101: 11030-11035.

Tamura K., Peterson,D., Peterson N., Stecher G., Nei M., KUMAR S. 2011. MEGA5: Molecular Evolutionary Genetics Analysis using Maximum Likelihood, Evolutionary Distance, and Maximum Parsimony Methods. Mol. Biol. Evol. 28: 2731-2739.

Thaler R., Brandstätter A., Meraner A., ChabiCOVSKi M., PARSON W., Zelger R., DAlla Via J., DALLINGER R. 2008. Molecular phylogeny and population structure of the codling moth (Cydia pomonella) in Central Europe: II. AFLP analysis reflects human-aided local adaptation of a global pest species. Mol. Phyl. Evol. 48: 838-849.

Thompson J. D., Higgins D. G., GiBson T. J. 1994. CLUSTAL W: improving the sensitivity of progressive multiple sequence alignment through sequence weighting, position-specific penalties and weight matrix choice. Nucl. Acids Res. 22: 4673-4680.

Timm A.E., GeERTSEMA H., WARnich L. 2010. Population genetic structure of economically important Tortricidae (Lepidoptera) in South Africa: a comparative analysis. Bull. Entomol. Res. 100: 421-431. 